\title{
PENGARUH LIFE REVIEW THERAPY TERHADAP KEMAMPUAN KOGNITIF LANSIA DEMENSIA DI PSTW PUSPAKARMA MATARAM
}

\author{
Desty Emilyani ${ }^{1}$, Awan Dramawan ${ }^{2}$ \\ 1,2 Jurusan Keperawatan/Poltekkes Kemenkes Mataram/Indonesia
}

\begin{abstract}
Abstrak
Melihat kembali kehidupan sebelumnya (Life Review Therapy) merupakan proses yang normal berkaitan dengan pendekatan terhadap proses kematian. Reintegrasi yang sukses dapat memberikan arti dalam kehidupan dan mempersiapkan seseorang untuk mati, tanpa disertai rasa cemas dan rasa takut. Hasil diskusi terahir tentang proses ini, menemukan melihat kembali kehidupan sebelumnya merupakan salah satu strategi untuk merawat masalah jiwa lansia. Desain penelitian ini, adalah Quasi Eksperiment dengan pendekatan One Group Pre-Test dan Post-Test. Sampelnya adalah lansia yang mengalami demensia yang berada di Panti Sosial Tresna Werdha "Puspakarma "Mataram dengan tehnik pengambilan sampel menggunakan Total Sampling denganjumlah responden 10 orang. Tehnik pengumpulan data mengunakan dokumentasi, wawancara, dan observasi dengan uji statistik menggunakan t-test. Hasil penelitian ini didapatkan bahwa dari 10 responden terdapat 9 kelayan mengalami gangguan kognitif berat dan 1 orang mengalami gangguan kognitif sedang, setelah diberikan Life Review Therapy kepada 10 Orang responden terjadi perubahan yang signifikan dimana ditemukan 7 orang responden dengan kategori kerusakan kognitif berat, 3 orang responden dengan kategori berat. Dengan hasil uji t-test dengan nilai $\mathrm{p} 0,005$ dengan tingkat kemaknaan $\leq 0,05$. Dapat disimpulkan bahwa setelah diberikan life review therapy terjadi perubahan pada tingkat kemampuan kognitif lansia. Sehingga Life Review Therapy lebih dapat diterapkan sebagai salah satu terapi modalitas.
\end{abstract}

Kata kunci: "Life Review Therapy, kognitif, demensia, lansia.

\section{THE EFFECT OF LIFE REVIEW THERAPY TOWARDS THE COGNITIVE ABILITIES OF ELDERLY WITH DEMENTIA AT PSTW PUSPAKARMA MATARAM}

\begin{abstract}
Looking back to the previous life (Life Review Therapy) is a normal process which relate to an approach to the process death. Successful reintegrating can give a meaning in life and prepare someone for the death, without accompanied by worry and fear. The last result of the discussion about this process is that looking back to the previous life represents one of the strategies to solve the mental problem of elderly. Design of this research is Quasi Experiments with One Group Pre-Test and PostTest. The sample is 10 elderly with demensia, residing in PSTW Puspakarma Mataram. Sampling Techniques used is total sampling. Data collections were using documentation, interview and observation. Data were analyzed using t-test. Results showed that there are 9 respondents suffer from
\end{abstract}


severe cognitive impaired and 1 responden with mild cognitive impaired prior to intervention. After given the Life Review Therapy, 7 respondents suffer from severe cognitive impaired and 3 respondents with mild cognitive impaired. T-test result in $\mathrm{P}=0,005$; with significance level $\leq 0,05$. It can be concluded that life review therapy,affects the change of the cognitive abilities of elderly with dementia. The "Life Review Therapy" is suggested to be applied as one of the therapy of modalities.

\section{Keyword: "Life Review Therapy, cognate, dementia, elderly.}

\section{PENDAHULUAN}

Peningkatan usia harapan hidup mengakibatkan peningkatan jumlah populasi Lansia yang berarti pula bertambahnya kebutuhan akan perawatan lansia. Kelompok lansia dipandang sebagai kelompok masyarakat yang berisiko mengalami gangguan kesehatan. Masalah keperawatan yang menonjol pada kelompok tersebut adalah meningkatnya disabilitas fungsional. Disabilitas fungsional pada lansia merupakan respons tubuh sejalan dengan bertambahnya umur seseorang dan proses kemunduran yang diikuti dengan munculnya gangguan fisiologis, penurunan fungsi, gangguan afektif, gangguan kognitif dan gangguan psikososial (Bondan P, 2006). Salah satu bentuk gangguan kognitif yang sering terjadi pada lansia adalah demensia (pikun).

Berdasarkan sejumlah hasil penelitian diperoleh data bahwa demensia seringkali terjadi pada usia lanjut yang telah berumur kurang lebih 60 tahun. Demensia tersebut dapat dibagi menjadi 2 kategori, yaitu: 1) Demensia Senilis ; 2) Demensia Pra Senilis. Sekitar 56,8\% lansia mengalami demensia dalam bentuk Demensia Alzheimer (4\% dialami lansia yang telah berusia 75 tahun, 16\% pada usia 85 tahun, dan $32 \%$ pada usia 90 tahun). Sampai saat ini diperkirakan \pm 30 juta penduduk dunia mengalami demensia dengan berbagai sebab (Santoso, 2002). Sedangkan di Indonesia pada tahun 2005 prevalensi demensia mencapai 191,4 kemudian pada tahun 2020 diperkirakan mencapai 314,1 dan pada tahun 2050 diperkirakan mencapai 932,0. oleh karena itu untuk menangani hal ini agar prevalensi demensia di Indonesia dari tahun ketahun tidak mengalami peningkatan dibutuhkan kerjasama dari berbagai pihak baik dari keluarga, tenaga kesehatan, dan instansi - instansi yang bergerak dibidang sosial.

Kemunduran fungsi intelektual sejalan dengan usia bukan tidak dapat dihindarkan. Sebenarnya terdapat perbedaan penampilan individu. Walaupun derajat tertentu dari ketidakpastian seperti pada penyebab suatu penyimpangan pada berfungsinya kognitif, hal yang paling penting adalah bahwa situasi tidak permanen dan dengan mudah dapat diubah dengan menggunakan tehnik latihan yang sederhana dan tidak mahal (Schaie \& Willis 1991).

Life Review Therapy merupakan salah satu terapi modalitas keperawatan yang dapat digunakan untuk meningkatkan kemampuan kognitif. Pada lansia, melihat kembali kehidupan sebelumnya (Life Review) merupakan proses yang normal berkaitan dengan pendekatan terhadap 
kematian. Reintegrasi yang sukses dapat memberikan arti dalam kehidupan dan mempersiapkan seseorang untuk menghadapi masa tua tanpa disertai dengan kecemasan dan rasa takut. Hasil diskusi terakhir tentang proses ini menemukan bahwa melihat kembali kehidupan sebelumnya merupakan salah satu strategi untuk merawat masalah kesehatan jiwa pada lansia (Team creative "nutrisi jiwa", 2008).

Menurut data dari PSTW "Puspa Karma" Mataram bahwa pada tahun 2015 terdapat 10 orang lansia yang mengalami demensia yang tinggal di panti tersebut dan belum mendapat perhatian terkait dengan masalah demensia yang dialami. Berdasarkan uraian di atas peneliti tertarik untuk mengetahui pengaruh Life Review Therapy terhadap kemampuan kognitif pada lansia dengan demensia di PSTW "Puspa Karma" Mataram.

\section{METODE}

penelitian ini adalah pendekatan Quasy Eksperiment dengan rancangan penelitian "One Group Pre Test-Post Test. Populasi penelitian adalah semua lansia yang ada di PSTW Puspakarma Mataram sebanyak 10 Orang. Sampel diambil menggunakan tehnik total sampling. Peneliti menerapkan Life Review Therapy yang terdiri dari empat sesi, yaitu membicarakan masa lalu dari kelayan dari masa anak - anak (berdiskusi mengenai permainan dimasa anak - anak), remaja (kegiatan keremajaan yang sering diikuti oleh lansia saat remaja di kampung masing - masing), dewasa (mengenai pernikahan), masa lansia. Pengumpulan data menggunakan kuesioner MMSE (Mini-Mental State Examination), pedoman pelaksanaan Life Review Therapy dan lembar observasi. Pengumpulan data menggunakan teknik studi dokumentasi, wawancara dan observasi. Kemampuan kognitif lansia diukur dengan menggunakan kuesioner MMSE. Variabel dependen adalah kemampuan kognitive lansia, sedangkan variabel independen adalah Life Review Therapy. Analisa data pada penelitian ini menggunakan uji statistik t-test dengan signifikan level 0,05 (5\%).

\section{HASIL PENELITIAN}

Dalam penelitian ini responden diberi perlakuan berupa terapi mengingat kembali masa lalu (Life Review Therapy) yang terdiri dari empat sesi yaitu sesi 1) menceritakan mengenai pengalaman masa anak - anak, sesi 2) menceritakan pengalaman masa remaja, sesi 3) menceritakan pengalaman masa dewasa, dan sesi 4) menceritakan pengalaman masa lanjut usia yang dialami kelayan. Setiap sesi sesi dilakukan pada hari yang berbeda, dimana sebelum dan setelah perlakuan diukur terlebih dahulu tingkat kemampuan kognitif lansia yang mengalami demensia sehingga didapatkan hasil sebagai berikut: 
1. Data karakteristik responden berdasarkan umur

Tabel 1 Distribusi responden berdasarkan umur

\begin{tabular}{cccc}
\hline No & Umur (tahun) & Frekuensi & Presentase(\%) \\
\hline 1 & $60-74$ & 4 & 40 \\
\hline 2 & $75-90$ & 6 & 60 \\
\hline 3 & $>90$ & 0 & 0 \\
\hline & Jumlah & 10 & 100 \\
\hline
\end{tabular}

Tabel 1 menunjukkan bahwa kelompok umur terbanyak adalah 75-90 tahun terbanyak sejumlah 6 orang responden $(60 \%)$.

2. Data distribusi responden berdasarkan tingkat pendidikan terakhir

Tabel 2 Distribusi responden berdasarkan tingkat pendidikan

\begin{tabular}{clcc}
\hline No & \multicolumn{1}{c}{ Kriteria } & Frekuensi & Presentase $\%$ \\
\hline 1 & Tidak Sekolah & 4 & 40 \\
\hline 2 & Tidak tamat SR/SD & 2 & 20 \\
\hline 3 & SR/SD & 3 & 30 \\
\hline 4 & SLTP/SMP sederajat & 1 & 10 \\
\hline & Jumlah & 10 & 100 \\
\hline
\end{tabular}

Tabel di atas menunjukkan sebagian besar lansia tidak sekolah yaitu 4 orang (40\%). Tingkat pendidikan tertinggi lansia adalah SLTP/SMP sederajat.

3. Data distribusi responden berdasarkan Jenis Kelamin

Tabel 3 Distribusi Responden berdasarkan Jenis Kelamin

\begin{tabular}{cccc}
\hline No & Jenis Kelamin & Frekuensi & Presentase $(\%)$ \\
\hline 1 & Laki-laki & 3 & 30 \\
\hline 2 & Perempuan & 7 & 70 \\
\hline & Jumlah & 10 & 100 \\
\hline
\end{tabular}

Tabel 3 menunjukkan bahwa sebagian besar responden berjenis kelamin perempuan yaitu sebanyak 7 responden $(70 \%)$.

4. Identifikasi tingkat kemampuan kognitif (Data Khusus) sebelum intervensi

Tabel 4 Distribusi Responden Berdasarkan Tingkat Kerusakan Kognitif Lansia Dengan Demensia Di PSTW "Puspakarma” Mataram Sebelum Dilakukan Life Review Therapy

\begin{tabular}{clccc}
\hline No & Kategori Kerusakan Intelektual Lansia & Frekuensi & $\begin{array}{c}\text { Presentase } \\
(\%)\end{array}$ \\
\hline 1 & Berat & & 9 & 90 \\
\hline 2 & Sedang & & 1 & 10 \\
\hline 3 & Ringan & & 0 & 0 \\
\hline & & Jumlah & 10 & 100 \\
\hline
\end{tabular}


Tabel 4 menunjukkan bahwa sebelum dilakukan Life Review Therapy sebagian besar responden mengalami tingkat kerusakan kognitif berat, yaitu sejumlah 9 orang responden (90\%). Berdasarkan data, dari 9 orang responden yang masuk dalam kategori kerusakan kognitif berat 6 orang $(66,67 \%)$ yang berjenis kelamin perempuan dan 3 orang $(33,33 \%)$ dengan jenis kelamin laki-laki.

5. Identifikasi tingkat kemampuan kognitif (Data Khusus) sesudah intervensi

Tabel 5 Distribusi Responden Berdasarkan Tingkat Kerusakan Intelektual Lansia Dengan Demensia Di PSTW "Puspakarma" Mataram Setelah Dilakukan Life Review Therapy.

\begin{tabular}{ccccc}
\hline No & \multicolumn{2}{c}{$\begin{array}{c}\text { Kategori Kerusakan Intelektual } \\
\text { Lansia Demensia }\end{array}$} & Frekuensi & Presentase (\%) \\
\hline 1 & Berat & & 7 & 70 \\
\hline 2 & Sedang & 3 & 30 \\
\hline 3 & Ringan & & 0 & 0 \\
\hline & & Jumlah & 10 & 100 \\
\hline
\end{tabular}

Tabel 5 menunjukkan bahwa setelah diberi perlakuan Life Review Therapy sebagian besar responden mengalami tingkat kerusakan kognitif berat sejumlah 7 orang responden (70\%), kemudian diikuti dengan kategori sedang sebanyak 3 orang responden $(30 \%)$. Berdasarkan data dari 7 orang responden seluruhnya (100\%) memiliki jenis kelamin perempuan.

6. Pengaruh Life Review Therapy terhadap kemampuan kognitif lansia

Tabel 6 Pengaruh Life Review Therapy terhadap kemampuan kognitif lansia dengan demensia di PSTW "Puspa Karma” Mataram.

\begin{tabular}{cccccc}
\hline \multirow{2}{*}{ No } & \multicolumn{4}{c}{ Tingkat Kemampuan Kognitif } & \multirow{2}{*}{ Peningkatan } \\
\cline { 2 - 5 } & \multicolumn{2}{c}{ Pre Test } & \multicolumn{2}{c}{ Post Test } & \\
\cline { 2 - 5 } & Skor & Kategori & Skor & Kategori & \\
\hline 1 & 18 & Berat & 25 & Sedang & +7 \\
\hline 2 & 17 & Berat & 21 & Berat & +4 \\
\hline 3 & 14 & Berat & 16 & Berat & +2 \\
\hline 4 & 17 & Berat & 24 & Sedang & +7 \\
\hline 5 & 25 & Sedang & 26 & Sedang & +1 \\
\hline 6 & 20 & Berat & 21 & Berat & +1 \\
\hline 7 & 15 & Berat & 18 & Berat & +3 \\
\hline 8 & 19 & Berat & 20 & Berat & +1 \\
\hline 9 & 15 & Berat & 15 & Berat & 0 \\
\hline 10 & 16 & Berat & 19 & Berat & +3 \\
\hline \multicolumn{7}{c}{} & 176 & 205 & & 29 \\
\hline
\end{tabular}

Dari tabel 6 dapat diketahui bahwa responden sebanyak 10 orang sebelum diberikan Life Review Therapy sebanyak 9 orang (90\%) berada dalam kategori kerusakan kognitif berat dan 1 orang (10\%) berada pada kategori kerusakan kognitif sedang. Setelah dilakukan Life Review Therapy 
sebanyak 7 orang $(70 \%)$ masih berada dalam kategori kerusakan kognitif yang berat dan 3 orang (30\%) berada pada kategori kerusakan kognitif sedang.

Hasil uji statistik menggunakan $t$-test, nilai sig (2-tailed) adalah $\mathrm{p}=0,005$, berarti $\mathrm{p} \leq 0,05$ maka hal ini menunjukkan bahwa Ho ditolak dan Ha diterima yang artinya bahwa ada pengaruh Life Review Therapy terhadap tingkat kemampuan kognitif (intelektual) lansia dengan demensia di PSTW "Puspakarma" Mataram.

\section{PEMBAHASAN}

1. Umur Responden

Hasil penelitian menunjukkan bahwa kelompok umur 75-90 tahun terbanyak sejumlah 6 orang responden (60\%), sedangkan kelompok umur 60-74 sebanyak 4 orang responden $(40 \%)$ dan kelompok umur > 90 tahun tidak ada. Kelompok lansia dipandang sebagai kelompok masyarakat yang berisiko mengalami gangguan kesehatan. Masalah keperawatan yang menonjol pada kelompok tersebut adalah meningkatnya disabilitas fungsional. Disabilitas fungsional pada lansia merupakan respons tubuh sejalan dengan bertambahnya umur seseorang dan proses kemunduran yang diikuti dengan munculnya gangguan fisiologis, penurunan fungsi, gangguan afektif, gangguan kognitif dan gangguan psikososial (Bondan P, 2006), salah satu bentuk gangguan kognitif yang sering terjadi pada lansia adalah demensia (pikun).

Berdasarkan sejumlah hasil penelitian diperoleh data bahwa demensia seringkali terjadi pada usia lanjut yang telah berumur kurang lebih 60 tahun. Demensia tersebut dapat dibagi menjadi 2 kategori, yaitu: 1) Demensia Senilis ; 2) Demensia Pra Senilis. Sekitar 56,8\% lansia mengalami demensia dalam bentuk Demensia Alzheimer (4\% dialami lansia yang telah berusia 75 tahun, $16 \%$ pada usia 85 tahun, dan 32\% pada usia 90 tahun) sampai saat ini diperkirakan \pm 30 juta penduduk dunia mengalami demensia dengan berbagai sebab (Oelly Mardi Santoso, 2002)

2. Tingkat pendidikan responden

Sebagian besar responden tidak sekolah yaitu sebanyak 4 orang (40\%), sedangkan responden yang mempunyai tingkat pendidikan tidak tamat SD/SR adalah 2 orang responden (20\%) dan responden yang mempunyai tingkat pendidikan SD/SR sebanyak 3 orang responden (30\%), dan yang tamat SMP sebanyak 1 orang (10\%). Pengalaman - pengalaman di dunia pendidikan berkorelasi positif dengan skor pada tes - tes intelegensi dan tugas - tugas pengolahan informasi, seperti ingatan (Verhaeghen, Marcoen \& Gossens, 1993; dalam Santrock, 2002). 
Bagi responden yang memiliki tingkat pendidikan yang lebih baik tentunya akan memiliki kemampuan yang lebih baik terhadap Atensi dan Kalkulasi. Kemampuan mengingat kembali hal-hal yang telah ditanyakan sebelumnya sebagian besar lansia yang tidak sekolah memiliki kemampuan mengingat yang lebih baik. Hal ini dikarenakan kemampuan mengingat lebih sering digunakan pada orang-orang yang tidak memiliki pendidikan formal.

3. Jenis kelamin responden

Sebagian besar responden adalah perempuan sebanyak 7 responden (70\%), dan responden laki - laki sebanyak 3 responden (30\%). Kaplan \& Saddock (1998), menyatakan bahwa faktor resiko untuk perkembangan demensia adalah pada wanita, terutama tipe Alzheimer, selain mempunyai sanak saudara tingkat pertama dengan gangguan tersebut, dan dan mempunyai riwayat cedera kepala. Lansia yang mengalami peningkatan kemampuan kogitif setelah diberikan Life Review Therapy dari kategori berat menjadi kategori sedang sebanyak 2 responden (20\%) dan seluruhnya memiliki jenis kelamin perempuan. Hal ini disebabkan karena responden sebagian besar perempuan (70\%).

4. Tingkat kemampuan kognitif lansia yang mengalami demensia sebelum dan sesudah dilakukan Life Review Therapy

Hasil penelitian menunjukkan bahwa sebelum dilakukan Life Review Therapy sebagian besar responden mengalami tingkat kerusakan kognitif berada pada kategori berat sejumlah 9 orang responden (90\%), kemudian diikuti dengan kategori sedang berjumlah 1 orang responden (10\%), dan tidak ada responden yang masuk dalam kategori kerusakan kognitif ringan. Setelah diberi perlakuan Life Review Therapy sebagian besar responden mengalami tingkat kerusakan kognitif berada pada kategori berat sejumlah 7 orang responden (70\%), kemudian diikuti dengan kategori sedang sebanyak 3 orang responden (30\%).

Menurut Schaie \& Willis menyumbangkan dukungan terhadap pernyataan tentang keluwesan perilaku pada usia dewasa lanjut. Mereka menyarankan bahwa sedikitnya harus tersedia tempat utuk didiami lansia, terobsesi bahwa penyimpangan kognitif bukan tidak dapat diperbaiki, tetapi lebih diakibatkan karena kurangnya penggunaan kognitif pada usia muda, dan masalah ini dapat diatasi oleh masyarakat dengan manipulasi lingkungan, termasuk memberikan tehnik latihan, sederhana dan pendidikan yang tidak mahal (Neil niven, 2000).

Pada lansia, melihat kembali kehidupan sebelumnya (Life Review) merupakan proses yang normal berkaitan dengan pendekatan terhadap kematian. Reintegrasi yang sukses dapat memberikan arti dalam kehidupan dan mempersiapkan seseorang untuk menghadapi masa tua tanpa disertai dengan kecemasan dan rasa takut. Hasil diskusi terakhir tentang proses ini menemukan bahwa melihat kembali kehidupan sebelumnya merupakan salah satu strategi untuk merawat masalah kesehatan jiwa pada lansia (Team creative "nutrisi jiwa", 2008).

Melalui pengalaman mengingat kembali kehidupan yang lalu, gejala yang sekarang dialami akan berangsur hilang dan perasaan damai serta nyaman yang mendalam akan 
muncul. Kadang-kadang ingatan yang muncul berhubungan dengan trauma masa kanak-kanak atau keadaan stres di dalam rahim. Akan tetapi umumnya masalah-masalah yang dihadapi pada kehidupan yang sedang dijalankanlah yang teratasi dengan metode ini (Suchufi \& Fauzi, 2008).

Butler (1963 dalam Harber, 2006) mengatakan bahwa secara universal terapi kenangan tidak dipicu oleh kecendrungan patologis seseorang dalam upaya menghindari rasional kehidupan, tetapi lebih fokus pada proses normal yang muncul dari keinginan individu untuk menikmati, tumbuh, mengatasi dan mengubah kehidupannya ke arah positif. Pengalamn hidup yang diceritakan atau diungkapkan seorang individu akan berdampak besar pada kesehatan mental individu, karena dengan mengungkapkan kisah hidupnya akan muncul perasaan lega, damai, serta terjalinnya keintiman. (Aini, dkk, 2014).

5. Pengaruh Life Review Therapy terhadap tingkat kemampuan kognitif lansia dengan demensia berdasarkan uji t-test

Hasil uji statistik menggunakan $t$-test, nilai sig (2-tailed) adalah $\mathrm{p}=0,005$, berarti $\mathrm{p}$ $\leq 0,05$ maka hal ini menunjukkan bahwa Ho ditolak dan Ha diterima yang artinya bahwa ada pengaruh Life Review Therapy terhadap tingkat kemampuan kognitif (intelektual) lansia dengan demensia di PSTW "Puspakarma" Mataram. Hal ini menunjukkan pengaruh yang nyata atau signifikan Life Review Tharapy terhadap peningkatan kemampuan kognitif lansia dengan demensia. Dari 10 (sepuluh) orang responden yang diberikan Life Review Therapy 1 (satu) responden yang tidak mengalami perubahan kategori kerusakan kognitif, 2 (dua) orang responden mengalami perubahan kategori dari tingkat kerusakan kognitif berat menjadi tingkat kerusakan kognitif sedang. Responden lainnya sebanyak 7 (tujuh) orang responden walaupun tidak mengalami perubahan kategori tingkat kerusakan kognitif tetapi terjadi peningkatan jumlah skor yang diperoleh berdasarkan MMSE (Mini Mental State Examination). Hal ini dapat terjadi karena pada saat diberikan Life Review Therapy kelayan tidak banyak menceritakan masa lalu yang pernah dilalui, berikut akan dibahas mengenai perubahan dari setiap komponen kognitif (orientasi, registrasi, atensi dan kalkulasi, mengingat dan kemampuan berbahasa) sebelum diberikan Life Review Therapy dan setelah diberikan Life Review Therapy.

a. Orientasi

Dari 10 item pertanyaan yang berkaitan dengan kemampuan orientasi terlihat rata - rata skor tertinggi (1) terlihat pada item pertanyaan no 7, semua responden masih mengingat daerah asal masing - masing dan pada item pertanyaan no 3-5 rata - rata skor kelayan adalah 0 , kelayan tidak bisa berorientasi mengenai tahun, bulan dan tanggal, sedangkan setelah diberikan Life Review Therapy item pertanyaan no 3 rata - rata skor berubah menjadi 1 . 
b. Registrasi

Dari 3 item pertanyaan untuk mengukur registrasi, rata-rata hanya bisa menjawab benar pada pertanyaan tentang alat yang digunakan untuk menyapu. Hal ini dapat dijelaskan karena kegiatan tersebut dilakukan setiap hari.

c. Atensi dan Kalkulasi

Untuk atensi dan kalkulasi, terdapat 5 item pertanyaan yang terkait dengan penghitungan jumlah benda. Seluruh responden memperoleh nilai 0 . Hal ini disebabkan juga oleh tingkat pendidikan seseorang, dimana sebagian besar yakni $40 \%$ responden tidak pernah bersekolah. $20 \%$ tidak tamat SD/SR.

d. Mengingat dan kemampuan bahasa

Sebagian besar responden mampu mengingat benda-benda yang baru disebutkan sebelumnya dan responden masih dapat mengerti perintah yang diucapkan oleh orang lain dalam hal ini oleh petugas.

Berdasarkan observasi yang dilakukan selama melaksanakan kegiatan Life Review Therapy dari awal sampai akhir petugas tidak mengalami kesulitan dalam berkomunikasi dengan lansia. Hal ini disebabkan karena lansia memang paling senang di ajak bicara terutama saat menceritakan tentang masa-masa yang telah dilaluinya. Sebagian besar responden dalam penelitian ini masih mampu mengingat kenangan masa lalu bersama teman atau sahabat dekatnya di waktu muda dulu, mampu menceritakan secara spontan dan jelas serta mampu mengingat hobinya di waktu masa muda dulu. Dapat dikatakan bahwa lansia masih mampu mengingat kenangan yang menyenangkan dalam memorinya. Responden juga mampu menanggapi feedback dari peneliti dengan baik mengenai saran dan masukan yang diberikan peneliti pada responden tersebut. Kelebihan dan kekurangan penelitian ini adalah terapi yang digunakan adalah hanya mengenai hal-hal yang menyenangkan bagi responden, sehingga tidak meninggalkan kenangan duka di masa lalunya. Jumlah responden dalam penelitian ini masih sedikit dan waktu yang singkat sehingga hasil kurang maksimal.

\section{KESIMPULAN}

Dapat disimpulkan bahwa kemampuan kognitif lansia meningkat setelah diberikan life review therapy yang artinya Life Review Therapy memberikan pengaruh yang signifikan terhadap peningkatan kemampuan kognitif lansia dengan demensia di PSTW "Puspakarma" Mataram. Diharapkan Life Review Therapy dapat diterapkan secara rutin di Panti Sosial Tresna Werdha "Puspakarma" Mataram sebagai terapi alternatif, disamping itu juga terapi juga sangat sederhana dan tidak memerlukan biaya. Lansia dapat tetap menjaga kemampuan kognitifnya dengan tetap menceritakan masa lalu yang pernah dilalui baik masa anak - anak, remaja, dewasa dan masa lansia, sehingga mereka dapat mengekspresikan mengenai perasaannya. Perlu dilakukan penelitian lanjutan mengenai pengaruh life review therapy terhadap tingkat kemampuan kognitif pada komunitas lansia yang berbeda seperti di 
panti yang lain atau diwilayah kerja puskesmas, yang dapat digunakan sebagai pembanding penelitian sebelumnya demi tercapainya derajat kesehatan dan kesejahteraan yang optimal untuk lansia.

\section{DAFTAR PUSTAKA}

Aini, MN, 2014. Pengaruh Life Review Therapy Terhadap Kualitas Hidup Lansia di Dinas Unit Pelaksana Teknis Pelayanan Sosial Lanjut Usia Kabupaten Bondowoso. Universitas Jember.

Alimul, Aziz. 2007. Metode Penelitian Keperawatan dan Tehnik Analisa Data. Salemba Medika. Jakarta

Arikunto. 2006. Prosedur Penelitian Suatu Pendekatan Praktek. Rineka Cipta. Jakarta

Aspiani, RY. 2014. Buku Ajar: Asuhan Keperawatan Gerontik. Jilid 1 dan Jilid 2. Trans Info Media. Jakarta.

Bondan, P., 2003. Pengaruh Umur, Depresi dan Demensia Terhadap Disabilitas Fungsional Lansia di PSTW Abiyoso dan PSTW Budi Dharma Provinsi di Yogyakarta (Adaptasi Model Neuman ) Bondanpagamil.com

Brunner \& Suddarth. 2001. Keperawatan Medikal Bedah. Edisi 3, volume 3. egc. Jakarta

Darmojo, Boedhi R \& Martono, Hadi. 2004. Geriatri Ilmu Kesehatan Usia Lanjut. Fakultas Kedokteran Universitas Indonesia. Jakarta

Depsos RI. 2002. Standarisasi Pelayanan Kesejahteraan Sosial Panti Sosial Tresna Werdha (PSTW). Jakarta.

Dharmono Suryo \& Samino. 2007 Anda Sering Lupa? Bisa Jadi Anda Terkena Demensia Alzheimer http: //www.medicastore.com

Harwono S dan Fitri H. S . 2001. Keperawatan Medikal Bedah: Proses Penuaan. Widya Medika. Jakarta.

Fashinistha. 2008. Usia Harapan Hidup. http:// fashinistha wordpress. Com./2008/09/11

Kaplan \& Saddock. 1997. Sinopsis Psikiatri. Edisi 7. jilid 1.Binarupa Aksara. Jakarta

Kuntjoro. 2002 Gangguan Psikologis dan Perilaku pada Demensia http://www.e-psikologi.com

2006. Demensia di Asia Fasifik sudah ada wabah.http:// apreportindonesia.com.

. 2006. Masalah Kesehatan Jiwa Lansia. Jakarta. http://www.e-psikologi.com

Neil, Niven. 2000. Psikologis Kesehatan. edisi 2. EGC. Jakarta.

Nugroho, Wahjudi. 2008. Keperawatan Gerontik dan Geriatri. Edisi 3. EGC. Jakarta.

Nursalam. 2012. Konsep dan Penerapan Metodologi Penelitian Ilmu Keperawatan. Salemba Medika. Jakarta

Maramis, WF. 2005. Catatan Ilmu Kedokteran Jiwa. Airlangga Univercity Press. Surabaya.

Purwaningsih, W, \& Karlina, I. (2010). Asuhan Keperawatan Jiwa dilengkapi Terapi Modalitas dan Standard Operating Prosedure (SOP), Yogyakarta: Nuha Medika.

Residen Psikiatri ULCA. 1997. Buku Saku Psikiatri.EGC. Jakarta. 
Republika. Usia Harapan Hidup. http://www.gooegle.com/custom?domains=lomboknews.com

Riskesdas. (2007). Laporan Hasil Riset Kesehatan Dasar Nasional, Badan Penelitian dan Pengembangan Kesehatan Departemen Kesehatan Republik Indonesia, Jakarta.

Santrock, jhon W. 2002. Life span developmen edisi 5 jilid 2. Universitas Airlangga. Jakarta.

Schufi \& Fauzi. 2008. Therapy Kenangan. http://www.mengingatmasalalu.com.

Setiabudhi \& Hardywinoto. 2005. Panduan Gerontologi Tinjauan dari Berbagai Aspek. PT.Gremedia Pustaka Utama. Jakarta.

Setyoadi \& Kushariyadi. (2011). Terapi Modalitas Keperawatan pada Klien Psikogeriatrik. Jakarta: Salemba Medika.

Stuart, G.W., 2005, Principles and Practice of Psychiatric Nursing, $9^{\text {th }}$ Edition. St. Louise: Mosby.

Susana,S.A. \& Hendarsih,S. (2012). Terapi Modalitas Keperawatan Kesehatan Jiwa. Jakarta: EGC.

Team Creative. 2008. Nutrisi Jiwa untuk Lansia. http:// nutrisijiwa.blogspot. com

Taruna, Yuda. 2002. Demensia. http://emedechinehealth.com

Yatim Faisal, 2003, Pikun (Demensia), Penyakit Alzheimer, dan Sejenisnya, Pustaka Populer Obor, Jakarta 